Acta vet. scand. $1981,22,238-245$.

From the National Veterinary Institute, Oslo and the Department of Animal Breeding, Agricultural University of Norway, Ås.

\title{
A WORKING MODEL FOR THE EVALUATION OF DIFFERENT IMMUNOLOGICAL TRAITS AS INDICATORS OF RESISTANCE TO INFECTION IN DAIRY CATTLE
}

By

Ø. Lie and $H$. Solbu

\begin{abstract}
LIE, $\emptyset$. and H. SOLBU: A working model for the evaluation of different immunological traits as indicators of resistance to infection in dairy cattle. Acta vet. scand. 1981, 22, 238-245. - In order to determine the relative value of different immunological traits as indicators of resistance to infection, an analysis was performed based on records of immunological traits in young bulls and "health card" records of clinical mastitis in their half sisters. The correlation analysis suggested that young bulls with high levels of serum immunoglobulin have half sisters with low mastitis frequency. A significant positive correlation was found between the antibody response peak against human serum albumin and susceptibility to mastitis. The results of this analysis should not be considered conclusive as the data were limited. Further work is required on a larger body of material. The model described here may be considered for future use as it enables immediate selection of animals.
\end{abstract}

immunology; genetic resistance; bovine mastitis.

In recent years selection for improved disease resistance has been considered an important factor in the prevention of bovine mastitis. This attitude has been justified by the apparent increase in the incidence of mastitis despite intensified conventional prevention programmes. Moreover, numerous studies have shown significant genetic influence on susceptibility or resistance to this complex disease (see review by Solbu 1978).

However, there is some disagreement as to which criteria should be used for selection: disease data, indicators of resistance or a combination of the two. 
In order to utilize genetically influenced defence mechanisms or marker traits, one has to find out if, and to what extent, the trait in question is correlated to resistance. This can be done experimentally by selecting animals for marker traits and subsequently having them challenged and tested with regard to resistance. Alternatively, lines selected for resistance to infection may be characterised immunogenetically.

However, both these approaches are time consuming and expensive, especially when working with cattle, as selection must involve a number of generations. A method which obviates this major disadvantage is here proposed and tested.

\section{MATERIAL AND METHODS}

\section{Immunological records}

At a performance-testing station 137 young bulls, comprising 15 groups of half sibs (sire families), were evaluated with regard to rate and magnitude of antibody response to human serum albumin (HSA). Records of both the primary and secondary response were included in the study. In addition, total serum immunoglobulin level was determined both prior to immunisation and following the antibody response. Significant genetic influence on antibody response and immunoglobulin levels has been shown (Lie 1979).

\section{Disease records}

Some of the sires of the young bulls were from abroad and consequently there were very few offspring of these bulls in the Norwegian cow population. However, six of these sires had produced sufficient daughters to be progeny tested with regard to disease frequency.

Data on disease frequency were available from the "health card" system which is a national disease recording scheme based on veterinary treatments. The disease records used in this study were those of clinical mastitis. The practical operation of this scheme is described by Solbu (1978).

The data on clinical mastitis originated from the health card records within a "control-year" (from 1st of September to 31st of August). Only first-lactating cows (heifers) which calved within the first four-month period of the "control-year" were considered, despite the lower frequency found in such animals. 
The reason for this selection was to give the cows approximately equal opportunity to become recorded as clinically diseased in the course of their lactation. Moreover, possible effects of disease in previous lactations are also avoided in this manner.

\section{Statistical methods}

The analysis involved more sires than those having offspring at the testing station. In total, 20 sires with 5060 daughters were included. Those six sires which had young bull offspring at the testing station had 201 daughters included in this analysis. The effect of sires on clinical mastitis was calculated by least squares (L.S.) analysis (Harvey 1960) and based on the following model:

$$
\begin{aligned}
& \mathrm{y}_{\mathrm{ijkl}}=\mu+\mathrm{a}_{\mathrm{i}}+\mathrm{b}_{\mathrm{j}}+\mathrm{c}_{\mathrm{k}}+\mathrm{e}_{\mathrm{ijkl}} \\
& \text { where } y_{i j k 1}=\text { the } 1^{\text {th }} \text { observation of clinical mastitis for } \\
& \text { the } k^{\text {th }} \text { sire, in the } j^{\text {th }} \text { level of culling in } \\
& \text { the } i^{\text {th }} \text { month of parturition. } \\
& \mu=\text { overall mean } \\
& a_{i}=\text { effect of the } i^{\text {th }} \text { month of parturition } \\
& b_{j}=\text { effect of the } j^{\text {th }} \text { level of culling } \\
& c_{k}=\text { effect of the } k^{\text {th }} \text { sire } \\
& \mathrm{e}_{\mathrm{ijk} \mathbf{l}}=\text { random error effect } \\
& \mathrm{i}=1,2, \ldots 4 \text { (only a } 4 \text { month period of calving was } \\
& \text { included) } \\
& \mathrm{j}=1,2 \quad \text { (the cows were either culled or not } \\
& \text { culled) } \\
& \mathrm{k}=1,2, \ldots 20 \quad(20 \text { sires were included in the ana- } \\
& \text { lysis) }
\end{aligned}
$$

Interaction between the independent variables was assumed to be absent.

The dependent variable, "clinical mastitis", was recorded as an "all or none trait", with value 1 for treated and 0 for not treated. Value 1 was used regardless of the number of treatments per cow. The effect of herd was eliminated by performing the analysis within herd.

The effect of sire on the immunological traits was determined by a similar L.S. model. Serum immunoglobulin level and antibody response to HSA were dependent variables, while the age and sire of the tested bull were the independent variables. 
Finally, a correlation analysis was carried out between the sires' estimated L.S.-constants for the immunological traits and for the disease trait (clinical mastitis).

\section{RESULTS}

Table 1 shows the relationship between clinical mastitis among first-lactating cows and some immunological characteristics among their half brothers at the testing station.

T a b l e 1. Correlations ( $r$ ) between sires' L.S.-constants for immunological traits measured in young bulls (trait 1) and L.S. constants for clinical mastitis recorded in their half sisters (trait 2 ).

\begin{tabular}{|c|c|c|c|}
\hline \multicolumn{2}{|c|}{ Trait 1} & Trait 2 & $\mathbf{r}$ \\
\hline \multicolumn{4}{|c|}{$\begin{array}{l}\text { Antibody response } \\
\text { to } H S A\end{array}$} \\
\hline Primary & $\mathrm{Ti} \quad 02 \cdots$ & Clinical mastitis & 0.40 \\
\hline response & Ti $03 * *$ & ”, & 0.25 \\
\hline titers $(\mathrm{Ti})$ & Ti (peak) & ” & $0.91 *$ \\
\hline Secondary & Ti $07 \cdots$ & , & 0.01 \\
\hline response & $\mathrm{Ti} \quad 08 \cdots$ & 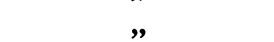 & -0.07 \\
\hline titers & $\mathrm{Ti}$ (peak) & 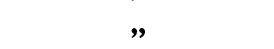 & $0.91 *$ \\
\hline \multicolumn{4}{|c|}{ Immunoglobulin level: } \\
\hline & $\operatorname{Ig}(0) *$ & , & -0.32 \\
\hline & $\operatorname{Ig}(1) * *$ & 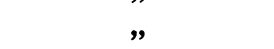 & -0.25 \\
\hline
\end{tabular}

* significantly different from zero, $P<0.01$.

* serum immunoglobulin level before and after immunization, respectively.

** antibody titers at a certain point of time in the primary and the secondary response, respectively.

A negative correlation can be interpreted as follows: Young bulls showing high antibody titers and immunoglobulin levels have half sisters with a low frequency of clinical mastitis.

It can be seen from Table 1, that only the immunoglobulin levels, $\operatorname{Ig}(0)$ and $\operatorname{Ig}(1)$ show notable negative correlations, though not significantly different from zero. On the other hand, high and significant correlations were found between the peak titers against HSA and susceptibility to mastitis. 


\section{DISCUSSION}

The negative correlation between immunoglobulin (Ig) level and mastitis susceptibility is not unreasonable. The Ig-level is a result of multiple specific antibody responses to naturally occurring immunogens, including mastitis pathogens. However, with only 6 sires included in the correlation analysis, the estimates were not significant. Consequently, these results should only be regarded as provisional and a larger body of experimental material should be studied for confirmation.

A surprisingly high and significant positive correlation was found between the peak titers against HSA and susceptibility to mastitis. A positive correlation can be interpreted in a number of ways:

Firstly, the antibody-complement system plays a minor role as a "killer" mechanism against udder pathogens as it is restricted to Gram-negative bacteria. Since the predominant mastitis causing organisms are Gram-positive cocci, particularly Staphylococcus aureus, the phagocytic activity of polymorphonuclear leucocytes (and to some extent macrophages) is considered to be the major active defence against udder infection (Schalm et al. 1966). Experimental studies in mice selected for high and low antibody response (Biozzi et al. 1972) have produced evidence for reduced antigen uptake and lysosomal digestion of high responder line macrophages (Wiener \& Bandieri 1974) and increased susceptibility in the high responder line to infections for which a proper host immunity is macrophage dependent (Biozzi 1972, Biozzi et al. 1975, 1979). With reference to the numerous studies carried out on defence mechanisms against udder infection (see review by Reiter \& Bramley 1975 ), there is reason to believe that it is the activity of phagocytic cells in the udder secretions rather than the antibody forming capacity which is the main limitation of this defence (Paape et al. 1979).

Secondly, the relatively low amount of HSA (2 mg per bull) used in the immunization might also to some extent explain this result. In laboratory animals responses to limiting doses of protein antigens and synthetic polypeptides have been found to be determinant specific and immune response (Ir) gene controlled (McDevitt \& Tyan 1968, see also review by Benacerraf \& Katz 1975). The antibody response to HSA in the bulls might there- 
fore reflect a certain response specificity and not a general capacity for antibody production.

However, the results presented should not be considered conclusive since only 6 sires were included in the final correlation analysis and, moreover, some of these had few daughters included in their progeny test for clinical mastitis, and some had few sons at the performance testing station.

This problem associated with a limited number of sires (elite bulls) will always exist within our breeding system. Consequently, the estimation of such correlations will always be subject to large sampling errors.

However, several of the young bulls that have been characterised with regard to defence mechanisms will soon have daughters in the Norwegian cow-population. These bulls will then be progeny tested with regard to clinical and perhaps also subclinical mastitis. These results can then be related directly to the phenotypic characters of the bulls themselves. For those becoming bull sires these results can also be related to their sons' results at the performance testing station. A model of such a scheme is presented in Fig. 1.

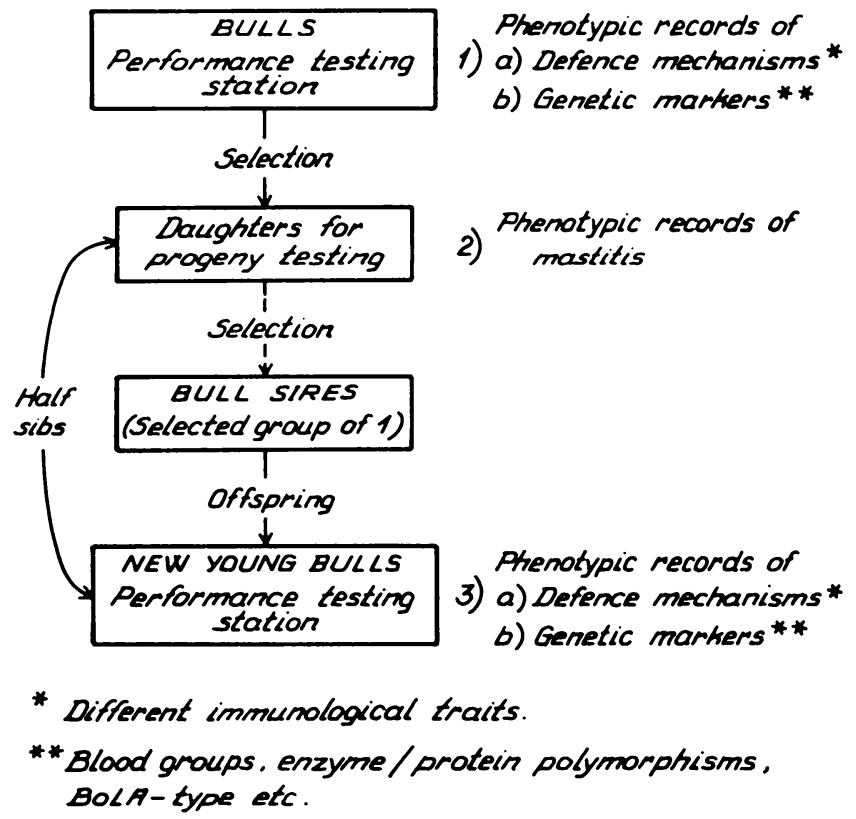

Fig u re 1. Model of a scheme for the evaluation of potential indicators of resistance to mastitis in cattle. 
Much work remains to be done before the conditions for an indirect selection for improved resistance to mastitis are fulfilled. For the time being, direct selection based on disease data is undoubtedly the most reliable method. However, as soon as genetic relationships between the different immunological traits and their relative importance in the defence against mastitis have been investigated in greater detail, the method of indirect selection should be considered for inclusion in standard selection programmes. In the work of preparing the conditions for such a selection, the model presented in this paper might act as a tool in revealing resistance indicators, especially when we have a larger volume of data and also a larger "battery" of immunological traits.

\section{REFERENCES}

Benacerraf, B. \& D. H. Katz: The nature and function of histocompability-linked immune response genes. In Immunogenetics and Immunodeficiency. Ed. B. Benacerraf. Medical and Technical Publications, Lancaster 1975, p. 117-177.

Biozzi, G.: In Genetic control of immune responsiveness. Relationship to disease susceptibility. Ed. H. O. McDevitt and M. Landy. Perspectives in Immunology, Academic Press, New York and London 1972.

Biozzi, G., C. Stiffel, D. Mouton, Y. Bouthillier \& C. Decreusefond: Cytodynamics of the immune response in two lines of mice genetically selected for "high" and "low" antibody synthesis. J. exp. Med. 1972, 135, 1072-1094.

Biozzi, G., C. Stiffel, D. Mouton \& Y. Bouthillier: Selection of lines of mice with high and low antibody response to complex immunogens. In Immunogenetics and Immunodeficiency. Ed. B. Benacerraf. Medical and Technical Publications, Lancaster 1975, p. $179-227$.

Biozzi, G., D. Mouton, O. A. Sant'Anna, H. C. Passos, M. Gennari, M. H. Reis, V. C. A. Ferreira, A. M. Heumann, Y. Bouthillier, O. M. Ibanez, C. Stiffel and M. Siqueira: Genetics of immunoresponsiveness to natural antigens in the mouse. In Current Topics in Microbiology and Immunology 1979, 85, 31-98.

Harvey, W. R.: Least-squares analysis of data with unequal subclass numbers. U.S. Dept. Agric., Agric. Res. Serv. 20-8 1960, 30-53.

Lie, $\emptyset .:$ Genetic analysis of some immunological traits in young bulls. Acta vet. scand. $1979,20,372-386$.

McDevitt, H. O.\& M. L. Tyan: Genetic control of the antibody response in inbred mice. J. exp. Med. 1968, 128, 1-11. 
Paape, M. J., W. P. Wergin, A. J. Guidry \& R. E. Pearson: LeukocytesSecond line of defence against invading mastitis pathogens. J. Dairy Sci. 1979, 62, 135-153.

Reiter, B. \& A. J. Bramley: Defence mechanisms of the udder and their relevance to mastitis control. Proc. Seminar on Mastitis Control, IDF Bulletin Document 1975, 85, 210-222.

Schalm, O. W., J. Lasmanis \& E. J. Carroll: Significance of leukocytic infiltration into the milk in experimental Streptococcus agalactiae mastitis in cattle. Amer. J. vet. Res. 1966, 27, 1537-1546.

Solbu, H.: Breeding for improved disease resistance, with special emphasis on a practical method of collecting data. EAAP, 29th Ann. Meeting, Stockholm 1978, C/1.03, $8 \mathrm{pp}$.

Wiener, E. \& A. Bandieri: Differences in antigen handling by peritoneal macrophages from the Biozzi high and low responder lines of mice. Eur. J. Immunol. 1974, 4, 457-463.

\section{SAMMENDRAG}

En modell for evaluering av forskjellige immunkarakterer som markфrer for resistens mot infeksjon hos storfe.

En analyse for evaluering av immunkarakterer som potensielle resistensmark $\varnothing$ rer ble gjennomf $\varnothing \mathrm{rt}$ på basis av følgende opplysninger: Immunologiske karakterer hos ungokser og helsekortdata over mastittfrekvenser til deres halvsøstre. Korrelasjonsanalyser tydet på at ungokser med høgt serum immunoglobin-nivå har halvs $\emptyset$ stre med lavest mastittfrekvens. Det ble funnet en sikker pasitiv sammenheng mellom antistoffrespons mot human serum albumin og mastitt-tilb $\varnothing$ yelighet. På grunn av materialets begrensning, er resultatene usikre og trenger f $\varnothing$ lgelig bekreftelse ved senere fors $\varnothing \mathbf{k}$. Den beskrevne modell vil sannsynligvis med fordel kunne benyttes i framtida særlig fordi den, i motsetning til andre modeller, kan avsl $\varnothing$ re interessante sammenhenger uten tidstap.

(Received January 16, 1981).

Reprints may be requested from: $\emptyset$. Lie, the National Veterinary Institute, P.O. Box 8156, Dep., Oslo 1, Norway. 